\title{
The Supply of Cholesterol and Fatty Acids for the Growth of Mycoplasmas
}

\author{
By A. W. RODWELL \\ Division of Animal Health, Animal Health Research Laboratory, \\ C.S.I.R.O., Parkville, Victoria 3052, Australia
}

(Accepted for publication I3 May 1969)

\begin{abstract}
SUMMAR Y
Mycoplasma strain $\mathrm{Y}$, serologically and biochemically related to Mycoplasma mycoides, grew well in a medium containing unesterified fatty acids, cholesterol and some samples of fatty acid-poor bovine serum albumin. With other samples of serum albumin, growth was accompanied by cellular lysis. Heating albumin solutions, treating them with charcoal, or varying the ratio of fatty acids to albumin, the concentration of cholesterol, or the order in which the lipid components were added to the medium, all influenced the amount of lysis. These effects may be due to varying interaction between fatty acids and cholesterol and between fatty acids and albumin. When fatty acids are firmly bound to albumin, their interaction with cholesterol is prevented, resulting in a cholesterol deficiency. Lysis was prevented by the addition of a heat-stable defatted serum protein fraction (fraction $\mathrm{C}$ ), or a pronase digest of fraction $\mathrm{C}$, both of which dispersed cholesterol.
\end{abstract}

\section{INTRODUCTION}

Media of partially defined composition for growth of Mycoplasma mycoides strain v 5, and Mycoplasma strain Y were described as media A and B (Rodwell, I956, 1960; Rodwell \& Abbot, I96I). These media contained a defatted serum protein fraction (fraction C). Deficiencies of glycerol, cholesterol or fatty acids resulted in marked morphological changes, cell death and lysis (Rodwell \& Abbot, 196I). Medium C (Rodwell, I967) containing defatted bovine serum albumin (BSA) and a pronase digest of BSA as undefined components, gave good growth of strain $\mathrm{Y}$, and was used to study the fatty acid growth requirements. The problem of supplying fatty acids in a non-toxic form, and of cholesterol in an available form, is considered further in this paper.

\section{METHODS}

Organism. Strain y, isolated from a goat (Laws, 1956), is serologically and biochemically related to Mycoplasma mycoides, but differs in that its growth is not improved by aeration.

Growth assays. Mycoplasmas for inoculating cultures were grown in BVFOS medium (Turner, Campbell \& Dick, 1935). The cultures were centrifuged, and the mycoplasmas suspended in an equal volume of $0.02 \mathrm{M}$-tris- $\mathrm{HCl}$ buffer containing ०.0I M- $\mathrm{MgSO}_{4}$ (TM). The suspensions were diluted I/IO or I/IOO in TM and one drop of diluted suspension containing approximately $10^{7}$ or $10^{6}$ viable particles was 
inoculated into $5 \mathrm{ml}$. volumes of test media in aluminium capped, $18 \mathrm{~mm}$. diameter, optically matched test tubes.

Measurement of growth. Growth was measured at intervals during incubation at $37^{\circ}$ by turbidity at $660 \mathrm{~m} \mu$. In some experiments, where it was suspected that turbidity might be an unreliable measure of growth, the synthesis of DNA was also measured by the incorporation of ${ }^{3} \mathrm{H}$ thymidine as described by Byfield \& Scherbaum (I966). Samples of the cultures $(90 \mu 1$.) were absorbed on discs of Whatman 3 MM filter paper, which were collected in cold $5 \%(\mathrm{w} / \mathrm{v})$ trichloracetic acid solution, and processed together at the end of the experiment.

Cultures were examined microscopically by dark-field illumination to assess the effects of nutrition on cellular morphology. Experience has shown (Rodwell \& Abbot, I96I) that extensive lysis (as revealed by electron microscopy) during growth of Mycoplasma cultures was always accompanied by a decreased turbidity, an increased viscosity-probably due to liberated DNA - and a tendency of the cells to aggregate into a sticky deposit.

Composition of media. Medium C was described previously (Rodwell, I967).

Medium $C_{I}$ had the same composition except that L-alanyl-L-alanyl-L-alanine

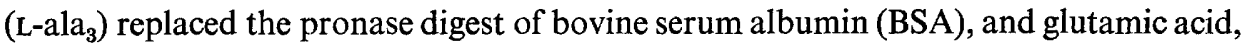
aspartic acid, cystine, biotin, leucovorin and vitamin $\mathrm{B}_{12}$ were omitted. It had the following composition: $\mathrm{Na}_{2} \mathrm{HPO}_{4}+\mathrm{NaH}_{2} \mathrm{PO}_{4}, \mathrm{pH} 7 \cdot 8,0 . \mathrm{I} 4 \mathrm{M} ; \mathrm{KCl}, 0.0 \mathrm{I} \mathrm{M} ; \mathrm{MgSO}_{4}$, $0.00 \mathrm{I} \mathrm{M}$; glucose, $0.04 \mathrm{M}$; glycerol, $5 \mathrm{~mm}$; spermine, 0.I mM; cholesterol, $0.08 \mathrm{mM}$; sodium oleate, $0.05 \mathrm{mM}$; sodium palmitate, $0.05 \mathrm{mM}$; 'fatty acid poor' bovine serum albumin (BSA), $0.8 \mathrm{~g} . / 1$; adenine, guanine and uracil, Io mg./l. each; thymine $5.0 \mathrm{mg} . / \mathrm{l}$; coenzyme $\mathrm{A}$, riboflavin, nicotinamide and thiamine, I.0 mg./l. each; DL $\alpha$-lipoic acid, O•I mg./l.; L-asparagine, L-glutamine, L-arginine, L-lysine, L-histidine, L-leucine, L-isoleucine and L-proline, I.0 $\mathrm{mM}$ each; DL-phenylalanine, DL-valine, DL-methionine, DL-serine, DL-threonine, DL-tryptophane and glycine, $2 \cdot 0 \mathrm{~mm}$ each;

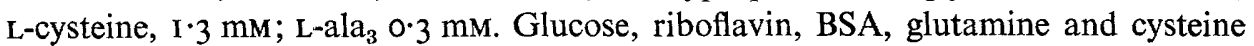
were added from sterile solutions to previously autoclaved medium. Glutamine and cysteine solutions were freshly prepared. Cholesterol was added as an aqueous dispersion prepared by the addition of I vol. of a solution in ethanol to 19 vol. stirred water at $65^{\circ}$. Coenzyme $A$ was added before autoclaving from a $0 \cdot I$ $\mathrm{mg} . / \mathrm{ml}$. solution containing dithiothreitol $\mathrm{I} \cdot 0 \mathrm{mg} . / \mathrm{ml}$. in phosphate buffer, $\mathrm{pH} 7 \cdot 0$.

In medium $\mathrm{C}_{2}$, L-alanine ( $\mathrm{I} \mathrm{mM}$ ) was substituted for $\mathrm{L}_{\text {-ala }}$, the concentration of cholesterol was increased to $0^{\circ} \mathrm{I} \mathrm{mM}$, 'fatty acid poor' BSA was replaced by charcoal treated BSA (BSA-Ch) and pronase digest of fraction $\mathrm{C}(\mathrm{PC}) 0.4 \mathrm{~g}$. 11 . was added.

Materials. Fraction C was prepared as described by Rodwell \& Abbot (196r). Carbohydrate reacting in the anthrone reaction was not detected in the product. A washed lipid extract (Folch, Lees \& Sloane Stanley, 1957) of one batch contained $0.38 \mu \mathrm{g}$. atom of phosphorus and a total of $0.9 \mu$ mole fatty acids (mainly palmitic, stearic and oleic acids) per $\mathrm{g}$. fraction $\mathrm{C}$. After extraction with chloroform + methanol $+\mathrm{N}$-hydrochloric acid $(\mathrm{I} 3 \cdot 3+6 \cdot 7+\mathrm{I} \cdot 0)$, the washed lipid extract contained a total of $2.6 \mu$ moles fatty acids per $\mathrm{g}$. fraction $\mathrm{C}$, while after hydrolysis of fraction $\mathrm{C}$ in $6 \mathrm{~N}-\mathrm{HCl}$ for $16 \mathrm{hr}$ at $100^{\circ}, 8 \cdot 2 \mu$ moles fatty acids per $\mathrm{g}$. were extracted. If these were present in phospholipids, this would correspond to a total of approximately $0.3 \%$ phospholipid, 
most of which is firmly bound. The total phosphorus content was $12 \cdot 0 \mu \mathrm{g}$. atom per $\mathrm{g}$. fraction C.

Pronase digest of fraction $\mathrm{C}$ (PC) was made by incubating a solution of fraction $\mathrm{C}$ (I00 mg.) at $\mathrm{pH} 7.5$ with $\mathrm{I} .0 \mathrm{mg}$. pronase (Calbiochem, Los Angeles, California) at $37^{\circ}$ for $24 \mathrm{hr}$. The $\mathrm{pH}$ was readjusted to $7 \cdot 5$, another $\mathrm{I} \cdot 0 \mathrm{mg}$. pronase added and incubation continued for a second $24 \mathrm{hr}$ period.

Samples of human and bovine serum albumin were obtained from Calbiochem; Pentex Incorporated, Kankakee, Illinois; Armour Ltd., Eastbourne, England; and Sigma Co., St Louis, Missouri. 'Fatty acid poor BSA' was manufactured by Pentex Incorporated. All these were depleted of bound fatty acids either by Goodman's (I957) method or by charcoal treatment (Chen, 1967). The charcoal (Nuchar C 190) was treated in vacuo in $10 \mathrm{~N}-\mathrm{HCl}$ for $\mathrm{I}$ to $2 \mathrm{hr}$ and washed with water. Charcoal could then be removed from albumin solutions by filtration. The treated solutions (BSA-Ch) were sterilized by filtration through a Seitz filter pad which had been extracted successively with chloroform + methanol, ethanol + acetic acid, ethanol and water. Protein was determined in the filtrate either by the method of Lowry, Rosebrough, Farr \& Randall (I95I) or by extinction at $280 \mathrm{~m} \mu$.

Amino acids (A Grade) were obtained from Calbiochem; fatty acids and cholesterol from Applied Science Inc., Pennsylvania, and alanyl peptides from Yeda Research and Development Co., Rehovoth, Israel. Cholesterol-4 ${ }^{14} \mathrm{C}$ was obtained from the Radiochemical Centre, Amersham, Bucks. and purified by thin layer chromatography (ITLC-SA, Gelman Instrument Co., Michigan; solvent isooctane + diethyl ether, 9:I). The main radioactive band was located by radioautography and eluted with ethanol.

Analytical methods. Cholesterol was determined by the method of Wycoff \& Parsons (I957), phosphorus by that of Bartlett (1959) as modified by Marinetti (1962), and radioactivity with a Packard Tri-Carb liquid scintillation spectrometer in a dioxane system (Bray, 1960). Fatty acids were estimated by gas liquid chromatography as described previously (Rodwell, I968) except that for the analysis of fatty acids in lipid extracts of fraction $\mathrm{C}$, the methyl esters were prepared by trans-esterification with boron trifluoride in methanol at $64^{\circ}$ for $2 \mathrm{hr}$.

Paper electrophoresis was performed in barbiturate buffer, $\mathrm{pH} 8 \cdot 6$, in an apparatus manufactured by LKB-Produkter, Sweden. The paper strips were stained for protein with brom phenol blue; ${ }^{14} \mathrm{C}$-cholesterol was located by radioautography.

\section{RESULTS}

Growth of Mycoplasma strain $Y$ in medium $C$. Medium $\mathrm{C}$ gave excellent growth of this strain from an inoculum of I to Io viable particles. The maximum yield, which was undiminished in serial subculture, was $0.35 \mathrm{mg}$. dry weight, and the maximum viable count was $6.0 \times 10^{9}$ colony forming units (c.f.u.) per ml. culture. Growth curves determined by viable counts, turbidity and by ${ }^{3} \mathrm{H}$ thymidine incorporation are shown (Fig. I). The mean doubling time as determined by all three methods was $\mathrm{I} \cdot 6$ to $\mathrm{I} \cdot 7 \mathrm{hr}$. Thymidine was incorporated at an exponential rate and then ceased abruptly. The turbidity continued to increase (at a decreasing rate) for about $4 \mathrm{hr}$ longer, perhaps because the mycoplasmas increased in mass after DNA replication ceased. In this experiment viable counts were discontinued after $24 \mathrm{hr}$ incubation, but in other 
experiments the count reached a maximum at about the same time as the turbidity. Increase in the number of viable particles after the cessation of DNA replication might be caused by the breaking up of filaments containing several 'DNA complements'. Medium $C_{I}$ gave the same growth rate and yield, and was used in subsequent experiments.

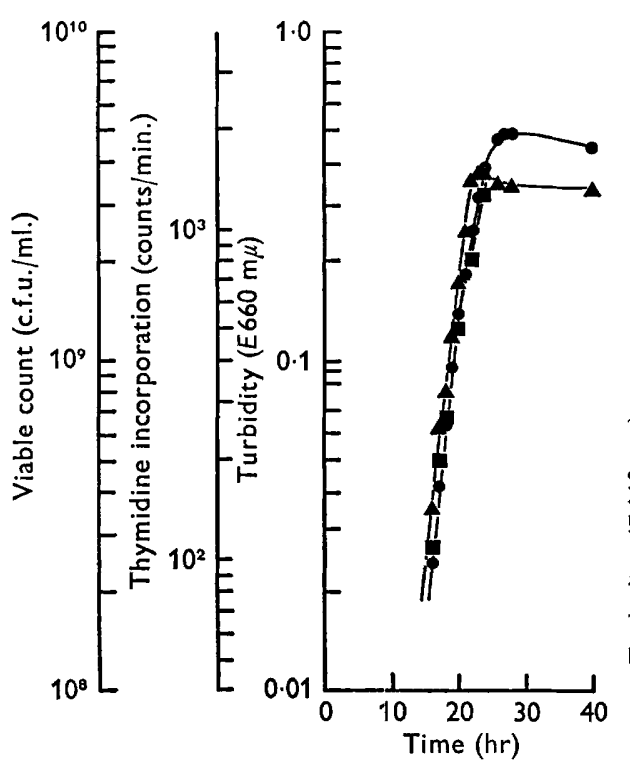

Fig. I

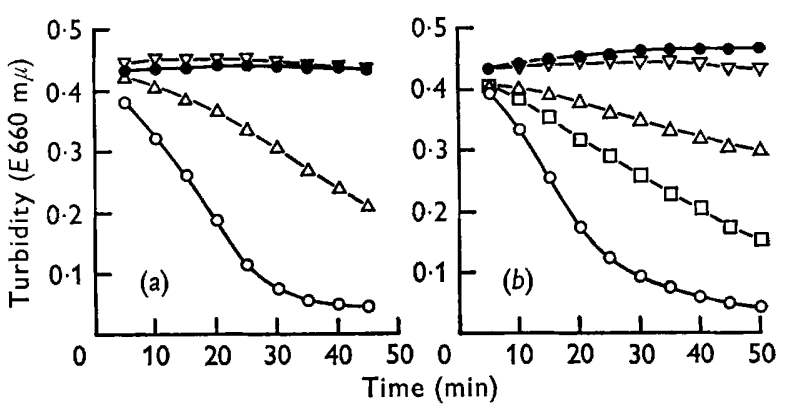

Fig. 2

Fig. I. Growth of Mycoplasma strain Y in medium C. Medium C (I00 ml.), modified by the substitution of ${ }^{3} \mathrm{H}$ thymidine $(2 \mathrm{mg}$. 1., specific activity $30 \mu \mathrm{C} . \mu$ mole) for thymine, was seeded with $2 \times 10^{5}$ colony forming units and dispensed in $5 \mathrm{ml}$. volumes in optically matched test tubes. Viable cell counts, $\mathbf{\square}$; turbidity, $\bullet$; and ${ }^{3} \mathrm{H}$ thymidine incorporation, $\boldsymbol{\Lambda}$, were determined on replicate tubes during incubation at $37^{\circ}$.

Fig. 2. Inhibition of oleate-induced lysis of Mycoplasma strain $\mathrm{Y}$ by bovine serum albumin (BSA). (a) Fraction $\mathrm{C}$ and pronase digest of fraction C (PC). (b). Phosphate buffer, $0.05 \mathrm{M}$, pH 7.4; sodium chloride, $0.25 \mathrm{M}$; sodium oleate, $2.5 \times 10^{-5} \mathrm{M}$, and BSA, fraction $\mathrm{C}$ or PC were incubated at $37^{\circ}$ for $10 \mathrm{~min}$. in optically matched test tubes; cell suspension added and turbidity measured during incubation at $37^{\circ}$. (a) $\bullet$, No oleate or BSA; O, oleate; $\triangle$, oleate + BSA $0.08 \mathrm{mg}$. $\mathrm{ml}$. (molar ratio $\mathrm{I} 5: \mathrm{I}$ ); $\nabla$, oleate+BSA, 0.2 mg. ml. (molar ratio 6: I). (b) 9 , No oleate or fraction $\mathrm{C}$; $\mathrm{O}$, oleate; $\triangle$, oleate $+0.05 \mathrm{mg}$. ml. fraction $\mathrm{C} ; \nabla$, oleate + $0.2 \mathrm{mg} . / \mathrm{ml}$. fraction $\mathrm{C} ; \square$, oleate $+0.2 \mathrm{mg}$. ml. PC.

\section{Growth-promoting properties of serum albumin}

It was concluded (Rodwell, 1967) that in medium $\mathrm{Cr}$, in which unesterified fatty acids are added in a total concentration of $0 . \mathrm{I} \mathrm{mM}$, albumin is required to bind fatty acids. The concentration of BSA required for growth increased with increasing fatty acid concentrations, and albumin was not required when the concentration of fatty acids was decreased below a critical value as in medium D. Mycoplasma cells are rapidly lysed by long chain monoenoic fatty acids in concentrations lower than those required for optimum growth, and lysis is prevented by BSA (Fig. 2a). It was found subsequently that not all samples of serum albumin were equally effective in promoting growth of strain $\mathrm{Y}$ in medium $\mathrm{C}_{\mathrm{I}}$. Two crystalline samples and six preparations of 
fraction $\mathrm{V}$ were tested, some of them before and after fatty acid depletion by Goodman's procedure or by charcoal treatment. Of these, only two gave good growth (equivalent to growth of strain $\mathrm{Y}$ in best media), whereas all of the others gave growth accompanied by various degrees of cellular lysis. The amount of lysis was greater with increasing albumin concentration (i.e. with decreasing fatty acid-albumin ratios, Fig. 3). but not when the concentrations of fatty acids were increased in proportion. Increasing the cholesterol concentration to $0.1 \mathrm{mM}$ or heating the albumin solutions at $56^{\circ}$ for $30 \mathrm{~min}$. decreased the amount of lysis and growth was now better at a lower fatty acid:albumin ratio (Fig. 3). Two samples of 'fatty acid poor BSA' which originally gave growth without appreciable lysis, gave growth with lysis after charcoal treatment.

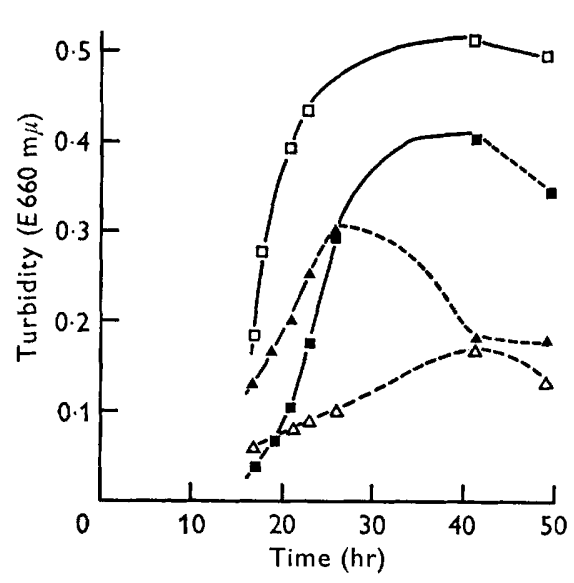

Fig. 3

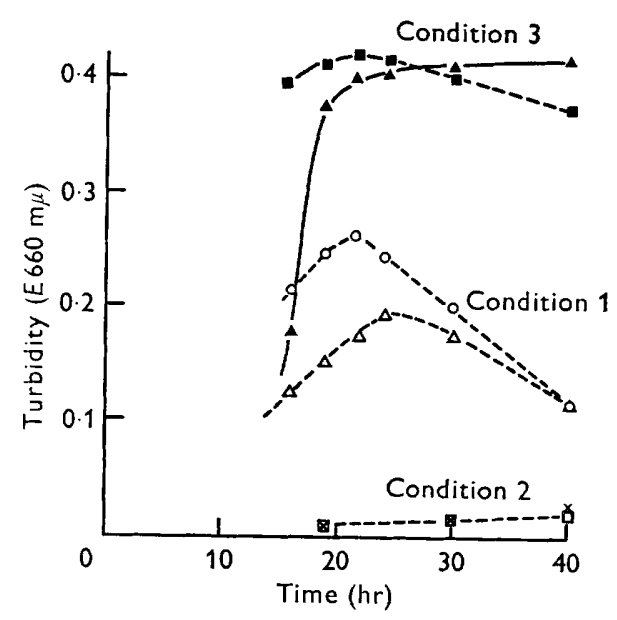

Fig. 4

Fig. 3. Effect of heating at $56^{\circ}$ for $30 \mathrm{~min}$. on the growth-promoting activity of bovine serum albumin (BSA) for Mycoplasma strain $\mathrm{Y}$ in medium $\mathrm{C}$ I. $\boldsymbol{A}$, BSA solution unheated, $\mathrm{I} \cdot 0 \mathrm{mg}$./ $\mathrm{ml}$.; $\triangle$, BSA solution unheated, $2.0 \mathrm{mg} . / \mathrm{ml}$.; $\mathbf{0}$, BSA solution heated, $\mathrm{r} \cdot 0 \mathrm{mg} . / \mathrm{ml}$.; $\square$, BSA solution heated, $2.0 \mathrm{mg} . / \mathrm{ml}$. ---, indicates lysis. The BSA was a crystalline sample; the molar ratio of fatty acids to BSA was $7: 1$ for a BSA concentration of $1.0 \mathrm{mg} . / \mathrm{ml}$.

Fig. 4. Effect of the order in which fatty acids and cholesterol dispersion were added to medium C I on the growth of Mycoplasma strain Y. In condition I, cholesterol dispersion and sodium salts of fatty acids were added before autoclaving the medium; BSA-Ch solution was added after autoclaving. In condition 2, cholesterol dispersion was added before autoclaving the medium; the fatty acid salts were incubated with the BSA-Ch solution at $37^{\circ}$ for 30 min., and the mixture added to the autoclaved medium. In condition 3, fatty acids were added as BSA-Ch fatty acid mixtures as in condition 2, but the cholesterol dispersion was autoclaved separately and added last. $\triangle$, Condition 1 , BSA-Ch $0.9 \mathrm{mg} . / \mathrm{ml}$.; 0 , condition 1 , BSA-Ch I. $8 \mathrm{mg} . / \mathrm{ml}$; $\square$, condition 2 , BSA-Ch $0.9 \mathrm{mg} . / \mathrm{ml}$; $\times$, condition 2 , BSA-Ch $\mathrm{I} \cdot 8 \mathrm{mg} . /$ $\mathrm{ml}$.; $\Delta$, condition 3 , BSA-Ch $0.9 \mathrm{mg} . / \mathrm{ml}$.; $\boldsymbol{\square}$, condition 3 , BSA-Ch $\mathrm{I} \cdot 8 \mathrm{mg} . / \mathrm{ml}$. -.-, indicates lysis.

Experiments in which the order in which cholesterol and fatty acids were added to the medium was varied suggested that these results might be explained by varying degrees of interaction between fatty acids and cholesterol on the one hand, and between fatty acids and albumin on the other. It may be seen (Fig. 4) that when cholesterol and fatty acids were autoclaved in the medium (condition I) there was growth with lysis; when cholesterol was autoclaved in the medium in the absence of 
fatty acids (condition 2), there was almost no growth; but when the cholesterol dispersion was autoclaved in the absence of salts and added to the medium last (condition 3) there was good growth with little apparent lysis. Turbidity, proportional to the amount of cholesterol, developed during autoclaving in condition 2, and was presumably due to cholesterol precipitation.

\section{Fraction $C$ and pronase digest of fraction $C(P C)$}

BSA could be replaced for growth of strain $\mathrm{Y}$ in medium $\mathrm{C}$ I by the heat-stable, defatted serum fraction $\mathrm{C}$, but growth was slower. Fraction $\mathrm{C}$ had about the same activity as BSA in preventing lysis of cells by oleate (Fig. $2 b$ ). When added before

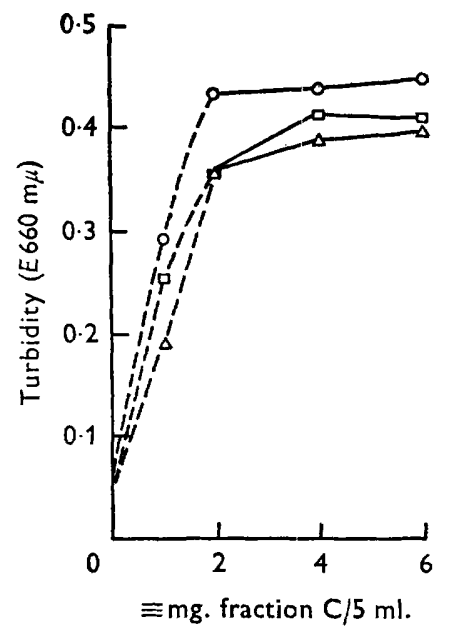

Fig. 5

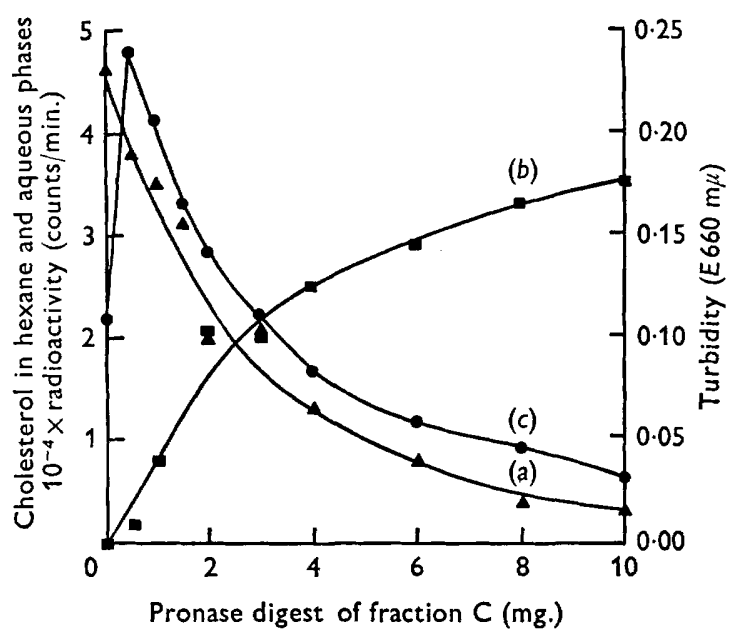

Fig. 6

Fig. 5. Effect of fraction $\mathrm{C}$, pronase digest of fraction $\mathrm{C}(\mathrm{PC})$ and dialysed $\mathrm{PC}$ on the growth of Mycoplasma strain $\mathrm{Y}$ in medium $\mathrm{CI}$ containing charcoal-treated bovine serum albumin (BSA-Ch). Fraction C (or PC), fatty acids and cholesterol were added before, and BSA-Ch after the medium was autoclaved. The cultures were incubated for $22 \mathrm{hr}$. O, Fraction $\mathrm{C}$; $\square, \mathrm{PC} ; \triangle, \mathrm{PC}$ after dialysis. ---, indicates lysis.

Fig. 6. Effect of pronase digest of fraction $\mathrm{C}(\mathrm{PC})$ on the distribution of cholesterol between hexane and aqueous phases after shaking with hexane, and on the turbidity of cholesterol dispersions after autoclaving in buffer solution: curve $(a)$ cholesterol in hexane phase; curve $(b)$ cholesterol in aqueous phase; curve $(c)$ turbidity. For curves $(a)$ and $(b), 0.7 \mathrm{mmole}$ $\mathrm{Na}_{2} \mathrm{HPO}_{4}+\mathrm{NaH}_{2} \mathrm{PO}_{4}$ buffer, $\mathrm{pH} 7 \cdot 8$; aqueous dispersion of ${ }^{14} \mathrm{C}$-labelled cholesterol, $\mathrm{I} \cdot 0 \mu \mathrm{mole}$ and PC (total volume $6.0 \mathrm{ml}$.) were incubated at $37^{\circ}$ for $30 \mathrm{~min}$. Hexane $(2.5 \mathrm{ml}$.) was added, the tubes shaken vigorously and centrifuged at 35,000 rev./min. for I hr (Spinco Model $\mathrm{L}$, rotor 40 ). Radioactivity was determined in the hexane and aqueous phases. For curve (c), $0.7 \mu$ mole $\mathrm{Na}_{2} \mathrm{HPO}_{4}+\mathrm{NaH}_{2} \mathrm{PO}_{4}$ buffer, $\mathrm{pH} 7.8$; aqueous cholesterol dispersion, $\mathrm{I} \cdot 0 \mu \mathrm{mole}$ and $\mathrm{PC}$ (total volume $6.0 \mathrm{ml}$.) were autoclaved at $10 \mathrm{lb}$. for $10 \mathrm{~min}$. and the turbidity measured at $420 \mathrm{~m} \mu$ in $\mathrm{I} \mathrm{cm}$. cuvettes.

autoclaving, it also prevented lysis in media containing BSA-Ch. Its ability to replace BSA for growth, and its fatty acid-binding activity, were largely destroyed by pronase digestion (Fig. $2 b$ ), but its ability to prevent lysis during growth in medium containing BSA-Ch was almost unaffected (Fig. 5). With BSA-Ch and either fraction C or PC, the order in which cholesterol and fatty acids were added made no apparent difference to growth. 
Fraction $\mathrm{C}$ disperses cholesterol. It prevented the precipitation of cholesterol when aqueous dispersions were heated in the presence of salts. When cholesterol dispersions were mixed with fraction $\mathrm{C}$ and buffer solution, and the mixture shaken with hexane, the cholesterol remained in the aqueous phase. Cholesterol-dispersing activity, in contrast to fatty acid-binding activity, was little changed by pronase digestion. The distribution of cholesterol (determined by radioactivity measurements) in the hexane and aqueous phases when a ${ }^{14} \mathrm{C}$-labelled cholesterol dispersion was mixed with buffer

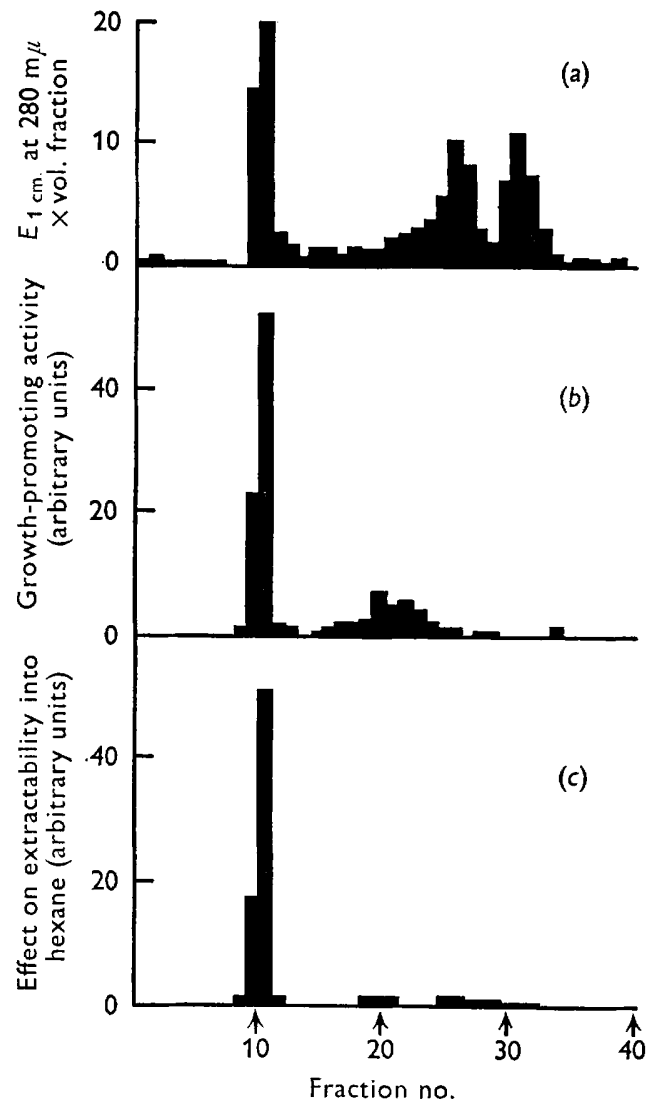

Fig. 7. Chromatography of pronase digest of fraction $C(P C)$ on a Sephadex $\mathrm{G}_{50}$ column. PC ( $80 \mathrm{mg}$.) in $\mathrm{I} .0 \mathrm{ml} .0 .02 \mathrm{M}$-ammonium bicarbonate was applied to a column of $80 \mathrm{ml}$. bed volume. The column was eluted with $0.02 \mathrm{M}$-ammonium bicarbonate, $2.7 \mathrm{ml}$. fractions collected, and assayed for extinction at $280 \mathrm{~m} \mu(a)$; growth-promoting activity in medium $\mathrm{C}_{2}(\mathrm{~b})$ : and cholesterol-dispersing activity $(c)$. Cholesterol-dispersing activity was measured by the effect on the distribution of cholesterol between hexane and aqueous phases under the conditions described in Fig. 6, cholesterol being determined colorimetrically in the hexane phases. The units of growth-promoting activity and cholesterol-dispersing activity were the amounts having activity equal to $\mathrm{I} \mathrm{mg}$. of $\mathrm{PC}$.

and various amounts of PC and the mixtures then shaken with hexane is shown in Fig. 6 (curves $a$ and $b$ ), and the effect of PC on turbidity when an aqueous cholesterol dispersion was autoclaved in buffer solution in Fig. 6 (curve $c$ ). In the presence of PC, only about $80 \%$ of the radioactivity was recovered in the hexane and aqueous phases; 
the remainder was probably present in an interfacial gel layer which was not analysed. The discrepancy and the amount of interfacial layer was even larger with fraction $\mathrm{C}$. The turbidity after autoclaving without PC was less than with a low concentration of PC. Cholesterol precipitated in large aggregates after autoclaving without PC; with low concentrations of PC the mixtures were opalescent and with higher concentrations they were clear.

The growth-promoting activity of PC was almost unchanged after dialysis (Fig. 5). PC was fractionated on a column of Sephadex $\mathrm{G}_{50}$ and the fractions assayed for material absorbing at $280 \mathrm{~m} \mu$ (Fig. $7 a$ ), for growth-promoting activity (Fig. $7 b$ ), and for their effect on the distribution of cholesterol between hexane and aqueous phases (Fig. 7c). Most of the growth-promoting activity, and the cholesterol-dispersing activity, were eluted in the void volume with about a twofold increase in specific activity.

Further purification of fraction $\mathrm{C}$ was obtained by iso-electric precipitation. After two precipitations at $\mathrm{pH} 4.8$, all of the growth-promoting activity was recovered in the fraction insoluble at $\mathrm{pH} 4.8$ (fraction $\mathrm{D}$ ), with about a twofold increase in specific activity. Much of the inactive material absorbing at $280 \mathrm{~m} \mu$ in the fractionation of PC (Fig. 7) was thus probably derived from inactive material present in fraction $\mathrm{C}$. Fraction D contained about $75 \%$ of the fatty acids present in fraction C.

Fraction $\mathrm{D}$ gave a broad diffuse band extending about $2 \mathrm{~cm}$. from the origin after paper electrophoresis. A mixture of fraction $\mathrm{D}$ in $\mathrm{O} \cdot \mathrm{I} \mathrm{M}$-phosphate buffer, $\mathrm{pH} 7 \cdot 4$, and ${ }^{14} \mathrm{C}$-cholesterol dispersion was incubated at $37^{\circ}$ for $30 \mathrm{~min}$. After paper electrophoresis of the mixture, the cholesterol remained in a narrow band at the origin, and was almost entirely separated from the protein.

\section{DISCUSSION}

The provision of cholesterol in an assimilable form and of fatty acids in a non-toxic form for the growth of mycoplasmas presents a problem. On the one hand, unesterified fatty acids cause rapid lysis by interacting with the cell membranes, and on the other, a fatty acid deficiency results in lysis during growth in an otherwise complete medium, attributable to impaired membrane synthesis. The problem is more difficult in the case of strains producing high yields of organisms for which fatty acids and sterol must be provided in relatively high concentrations. Strain $\mathrm{x}$, for example, incorporates about $60 \mu$ moles fatty acids and $30 \mu$ moles cholesterol per 1 . of culture during growth in medium $\mathrm{C}_{2}$.

Medium C contained BSA to bind fatty acids (Rodwell, 1967). It is likely that, in this medium, cholesterol is dispersed by an interaction with fatty acids. Some samples of BSA gave growth accompanied by cellular lysis, and other samples which originally gave growth without lysis, gave growth with lysis after charcoal treatment. These samples may bind fatty acids more firmly, thus preventing their interaction with cholesterol. The poor growth and lysis may therefore be due to a cholesterol deficiency. The availability of fatty acids for growth may also differ with different albumin preparations. Kessler, Demeny \& Sobotka (I967) showed a twofold difference in the rate at which palmitate was taken up by tissues from fatty acid + albumin complexes formed by two different methods.

Smith, Lecce \& Lynn (I954) described a defatted serum lipoprotein for growth of some strains of sterol-requiring mycoplasmas, and Smith \& Boughton (I960) postu- 
lated that it was required for cholesterol incorporation. Rodwell (1956) described a heat-stable defatted serum protein fraction (fraction $\mathrm{C}$ ) and suggested that fraction $\mathrm{C}$, cholesterol and fatty acids might interact to provide a non-toxic source of fatty acids for growth of Mycoplasma mycoides. Rodwell \& Abbot (I96I) later suggested that fraction $\mathrm{C}$ might also be required for cholesterol incorporation. Evidence that it binds fatty acids and disperses cholesterol is presented in this paper.

Fraction $\mathrm{C}$ is thought to consist largely of a defatted serum lipoprotein. Cholesterol was bound by the apoprotein of human high-density serum lipoprotein only when phospholipids were also bound (Sodhi \& Gould, 1967). Fraction C contains small amounts of firmly bound lipid, but whether this is essential for the cholesterol interaction, the nature of the interaction, and whether fraction $C$ is related to the apoprotein of a serum lipoprotein, were not determined.

I wish to thank Mr B. Zwolak for his capable technical help.

\section{REFERENCES}

Bartlett, G. R. (1959). Phosphorus assay in column chromatography. J. biol. Chem. 234, 466.

BraY, G. A. (I960). A simple efficient liquid scintillator for counting aqueous solutions in a liquid scintillation counter. Analyt. Biochem. I, 279.

Byfield, J. E. \& Scherbaum, O. H. (1966). A rapid radioassay technique for cellular suspensions. Analyt. Biochem. 17, 434 .

CHEN, R. F. ( I967). Removal of fatty acids from serum albumin by charcoal treatment. J. biol. Chem. 242, 173.

Folch, J., Lees, M. \& Sloane Stanley, G. H. ( 1957). A simple method for the isolation and purification of total lipids from animal tissues. J. biol. Chem. 226, 497.

Goodman, D. S. (1957). Preparation of human serum albumin free of Iong-chain fatty acids. Science, N.Y. 125, 1296.

Kessler, J. I., Demeny, M. \& Sobotka, H. (1967). Rates of tissue uptake of palmitic acid-I-14C complexed with albumin by two different procedures. J. Lipid Res. 8, 185.

LAws, L. (1956). A pleuropneumonia-like organism causing peritonitis in goats. Aust. vet. J. 32, 326.

Lowry, O. H., Rosebrough, N. J., Farr, A. L. \& Randall, R. J. (I95I). Protein measurement with the Folin phenol reagent. J. biol. Chem. I93, 265.

MARINETTI, G. V. (1962). Chromatographic separation, identification, and analysis of phosphatides. J. Lipid Res. 3, 1 .

Rodwell, A. W. (1956). The role of serum in the nutrition of Asterococcus mycoides. Aust. J. biol. Sci. 9, 105.

Rodwell, A. W. (1960). Nutrition and metabolism of Mycoplasma mycoides var. mycoides. Ann. N.Y. Acad. Sci. 79, 499.

Rodwell, A. W. (1967). The nutrition and metabolism of Mycoplasma: progress and problems. Ann. N.Y. Acad. Sci. r43, 88.

RoDwell, A. W. (1968). Fatty acid composition of Mycoplasma lipids: biomembrane with only one fatty acid. Science, N.Y. $\mathbf{6 6 0}$, 1350.

Rodwell, A. W. \& Aввот, A. (196I). The function of glycerol, cholesterol and long-chain fatty acids in the nutrition of Mycoplasma mycoides. J. gen. Microbiol. 25, 201.

Smith, P. F. \& Boughton, J. E. (1960). Role of protein and phospholipid in the growth of pleuropneumonia-like organisms. J. Bact. 8o, 851 .

SMTth, P. F., LeCCE, J. G. \& LyNN, R. J. (1954). A lipoprotein as a growth factor for certain pleuropnoumonia-like organisms. J. Bact. 68, 627.

SoDHI, H. S. \& GoulD, R. G. (1967). Combination of delipidized high density lipoprotein with lipids. J. biol. Chem, 242, I 205.

Turner, A. W., Campbell, A. D. \& Dick, A. T. (1935). Recent work on pleuropneumonia Contagiosa boum in North Queensland. Aust. vet. J. 11, 63.

Wycoff, H. D. \& Parsons, J. (I957). Chromatographic micro-assay for cholesterol and cholesterol esters. Science, N.Y. 125, 347. 